\title{
Cannibalism in mosquito larvae during microbial larvicide potency tests
}

\author{
Igor Uspensky and Sergei Braun*
}

Department of Biological Chemistry, A. Silberman Institute of Life Sciences, The Hebrew University of Jerusalem, Jerusalem, Israel

* deceased

\begin{abstract}
We observed instances of cannibalism (intraspecific predation) among intra-instar larvae of Culex pipiens Linnaeus, 1758 while performing a bioassay of Lysinibacillus sphaericus (formerly named Bacillus sphaericus) larvicide, when the larvae were exposed to the larvicide for $48 \mathrm{~h}$ in the absence of food. Larvae without symptoms of poisoning attacked and devoured those visibly affected. Cannibalism was more prevalent in $1^{\text {st }}-2^{\text {nd }}$ instar larvae than in $3^{\text {rd }}-4^{\text {th }}$ instar. This phenomenon should be taken into account when interpreting the results of larvicide bioassays, especially when the exposure lasts over $24 \mathrm{~h}$. The necessity of creating optimal conditions for organisms tested is emphasised.
\end{abstract}

Key words: bioassay, larval feeding, larval starvation, intraspecific predation, Culex pipiens, Lysinibacillus sphaericus (Bacillus sphaericus)

Microbial larvicides are effective and widely used agents, which may at some point replace chemicals in controlling the aquatic stages of dipteran vectors of human pathogens, such as malaria parasites, filariae and numerous viruses (Margalit et al. 1983, Becker and Margalit 1993, Uspensky 1996, Becker 1998, Regis et al. 2000, Fillinger et al. 2003, Lacey 2007, Berry 2011, Dambach 2018). Avariety of factors have been reported to affect the outcomes of laboratory-based bioassays of potential microbial larvicide (Davidson 1985, Becker and Margalit 1993, Lacey 1997, Skovmand and Becker 2000).

At the same time, no special schedule of larval maintenance during bioassay has ever been suggested. In our tests of Lysinibacillus sphaericus (formerly and best known as Bacillus sphaericus) against Culex pipiens Linnaeus, 1758 larvae, we noticed that in some experiments the final numbers of larvae (live and dead) in test dishes were significantly reduced relative to the initial numbers. Upon close observations it became clear that this reduction was caused by some larvae being cannibalised by others. This phenomenon is highly relevant to the design and interpretation of bioassays since it may skew the value of larvicide efficiency if not taken into account, but unfortunately the phenomenon has never been extensively described in the literature (Zaritsky and Khawaled 1986). To determine the prevalence and impact of larval cannibalism, we performed a series of tests under several bioassay conditions.

\section{MATERIALS AND METHODS}

Standard preparation of Lysinibacillus sphaericus 2362 larvicide was supplied by the Pasteur Institute, Paris, France. The laboratory colony of Culex pipiens was initiated from the eggs supplied by the Laboratory of Entomology, Ministry of Public Health, Israel. The colony originated in Lower Galilee, Israel, and has been maintained in the Laboratory of Entomology for over ten years. The maintenance of mosquitoes was as described earlier (Uspensky et al. 1998). Two groups of larvae were used in the experiments: the late $1^{\text {st }}-2^{\text {nd }}$ and the late $3^{\text {rd }}-$ early $4^{\text {th }}$ instars.

Freeze-dried larvicide was suspended in deionised water $(5 \mathrm{mg} / \mathrm{ml})$, homogenised on the Vortex mixer with glass beads (diameter $=3 \mathrm{~mm}$ ), and diluted in deionised water to the desired concentration just before the experiment. All tests were carried out in Petri dishes (diameter $=7 \mathrm{~cm}$ ). Larvae were removed from large jars where they were reared with abundant nutrition (powdered dog food supplemented with amino acids) and placed into test dishes with deionised water.

Special attention was paid to the conditions of the larvae, so that only specimens without any signs of morphological or behavioral abnormalities were selected for testing. The larvae were kept in Petri dishes without food for not more than $1 \mathrm{~h}$ before the introduction of larvicide. Following our standard procedure (Klein et al. 2002), we defined one larva per $1.0 \mathrm{ml}$ of water volume as the 'normal' density, and used 20 larval specimens in 20 $\mathrm{ml}$ of water per test dish, unless specified otherwise. Six to eight concentrations of L. sphaericus larvicide were tested, each in five 
Table 1. Mortality and cannibalism of larvae of Culex pipiens exposed to Lysinibacillus sphaericus 2362 larvicide under different feeding regimens (mean $\pm \mathrm{SD}$ )

\begin{tabular}{|c|c|c|c|c|c|c|c|c|}
\hline \multirow{3}{*}{$\begin{array}{l}\text { Concentration of } \\
\text { larvicide }(\mu \mathrm{g} / \mathrm{ml})\end{array}$} & \multicolumn{2}{|c|}{$\begin{array}{l}\text { Larval mortality (\%) in tests } \\
\text { with feeding after } 24 \mathrm{~h} \text { of } \\
\text { exposure }\end{array}$} & \multicolumn{2}{|c|}{$\begin{array}{l}\text { Larval mortality (\%) in tests } \\
\text { without feeding for } 48 \mathrm{~h} \text { of } \\
\text { exposure }\end{array}$} & \multicolumn{4}{|c|}{ Cannibalism (\%) in tests without feeding for $48 \mathrm{~h}$ of exposure } \\
\hline & \multirow[b]{2}{*}{$1^{\text {st }}-2^{\text {nd }}$ instars } & \multirow[b]{2}{*}{$3^{\text {rd }}-4^{\text {th }}$ instars } & \multirow[b]{2}{*}{$1^{\text {st }}-2^{\text {nd }}$ instars } & \multirow[b]{2}{*}{$3^{\text {rd }}-4^{\text {th }}$ instars } & \multicolumn{2}{|c|}{$1^{\text {st }}-2^{\text {nd }}$ instars } & \multicolumn{2}{|c|}{$3^{\text {rd }-4^{\text {th }} \text { instars }}$} \\
\hline & & & & & $\begin{array}{l}\text { from total } \\
\text { number of } \\
\text { larvae }\end{array}$ & $\begin{array}{l}\text { from total } \\
\text { mortality } \\
\text { (mean) }\end{array}$ & $\begin{array}{l}\text { from total } \\
\text { number of } \\
\text { larvae }\end{array}$ & $\begin{array}{l}\text { from total } \\
\text { mortality } \\
\text { (mean) }\end{array}$ \\
\hline 0.00125 & 0 & ND & $1 \pm 2.4$ & ND & 0 & 0 & ND & ND \\
\hline 0.0025 & $7 \pm 7$ & $1 \pm 2$ & $8 \pm 5$ & 0 & $3 \pm 2$ & 38 & 0 & 0 \\
\hline 0.005 & $23 \pm 12$ & $4 \pm 2$ & $25 \pm 7$ & $5 \pm 5$ & $22 \pm 7$ & 88 & $3 \pm 2$ & 60 \\
\hline 0.01 & $49 \pm 12$ & $18 \pm 10$ & $48 \pm 12$ & $17 \pm 5$ & $46 \pm 12$ & 96 & $11 \pm 2$ & 65 \\
\hline 0.02 & $76 \pm 12$ & $39 \pm 12$ & $80 \pm 5$ & $42 \pm 7$ & $32 \pm 10$ & 40 & $16 \pm 5$ & 38 \\
\hline 0.04 & $89 \pm 10$ & $65 \pm 12$ & $87 \pm 10$ & $70 \pm 7$ & $7 \pm 5$ & 8 & $15 \pm 5$ & 21 \\
\hline 0.08 & 100 & $91 \pm 7$ & $99 \pm 2$ & $93 \pm 10$ & 0 & 0 & $3 \pm 2$ & 3 \\
\hline 0.16 & ND & $99 \pm 2$ & ND & 100 & ND & ND & 0 & 0 \\
\hline 0.32 & ND & 100 & ND & 100 & ND & ND & 0 & 0 \\
\hline $\begin{array}{l}\text { Control (no } \\
\text { larvicide) }\end{array}$ & $1 \pm 2.4$ & 0 & $7 \pm 5$ & $5 \pm 2$ & $7 \pm 5$ & 100 & $5 \pm 2$ & 100 \\
\hline $\mathrm{LC}_{50} \pm \mathrm{SD}(\mu \mathrm{g} / \mathrm{ml})$ & $0.010 \pm 0.002$ & $0.029 \pm 0.005$ & & & & & & \\
\hline
\end{tabular}

replicates (i.e., a total of 100 larvae for each concentration). In the first series of tests with L. sphaericus, a drop of brewer's yeast suspension $(10 \% \mathrm{w} / \mathrm{w})$ was added $24 \mathrm{~h}$ after toxin introduction and exposure was continued for another $24 \mathrm{~h}$; in the second series, no food was added during the $48 \mathrm{~h}$ of exposure to the larvicide. Larval mortality was recorded after $48 \mathrm{~h}$ of exposure to the larvicide.

Additional tests were performed with $L$. sphaericus larvicide at a high density of larvae of the $1^{\text {st }}-2^{\text {nd }}$ instars (one larva per 0.33 $\mathrm{ml}$ of water volume, or 60 larvae in $20 \mathrm{ml}$ per test dish) and no addition of food during the 48-h exposure. Four concentrations of the larvicide were used with four replicates for each concentration (a total of 240 larvae per concentration). Larval mortality was recorded after $48 \mathrm{~h}$ of exposure for L. sphaericus.

The mean values of larval mortality and cannibalism with standard deviation (SD) were calculated for each concentration of larvicide from all replicates.

Since we paid special attention to the conditions of the larvae selected for the tests, we did not observe appreciable mortality in the control dishes with feeding but without larvicides (the only larva of $1^{\text {st }}-2^{\text {nd }}$ instars, which died in a control dish with feeding [Table 1], appears to have been injured during transfer from a jar into the dish). Thus, Abbott's correction was not applicable to our data. Cannibalised larvae have been counted as dead. The mean value of $\mathrm{LC}_{50}$ and standard deviation were calculated by the log-probit analysis using POLO-PC software.

In the second series of tests (without larval feeding) with normal and high larval density our main interest was connected with cannibalistic larval behavior and the values of $\mathrm{LC}_{50}$ were not calculated. The significance of differences between the values of larval mortality and cannibalism was estimated according to Student's $t$-test. The difference between values was considered significant if $P \leq 0.05$.

\section{RESULTS}

In test dishes with normal larval density (20 larval specimens in $20 \mathrm{ml}$ per dish) where larvae received no food during the 48-h exposure to Lysinibacillus sphaericus larvicide, the final numbers of larvae were substantially reduced compared to their initial numbers, sometimes by as much as $50 \%$. In addition to live and dead larvae, we observed significant numbers of fragments of sclerotised body parts (head capsule, thoracic segments), single hairs and setae. Continuous observation showed that after 24-25 hours of exposure, larvae without symptoms of poisoning began to attack the affected larvae ingesting the soft parts of their body (abdominal segments).

Both the number of cannibalised larvae of the $1^{\text {st }}-2^{\text {nd }}$ instars and their contribution to total mortality peaked around larvicide concentrations of $\mathrm{LC}_{25}$ to $\mathrm{LC}_{50}$ where they accounted for between $88 \%$ and $96 \%$ of total mortality (Table 1). At higher concentrations of larvicide, most larvae died within the first $24 \mathrm{~h}$ of the test, whereas at lower concentrations cannibalism was rare. We have not observed larvae without symptoms of poisoning falling prey to other larvae. The numbers of cannibalised specimens per dish were much lower among the $3^{\text {rd }}-4^{\text {th }}$ instar larvae than among those of $1^{\text {st }}-2^{\text {nd }}$ instar, and their prevalence in relation to larvicide concentration followed approximately the same pattern, with absolute numbers increasing from $\mathrm{LC}_{20}$ to $\mathrm{LC}_{70}$, and their contribution to total mortality peaked around $\mathrm{LC}_{5}$ to $\mathrm{LC}_{20}$ at $60 \%$ to $65 \%$ mortality, and decreased at higher concentrations (Table 1). In control dishes where the larvae had no food for $48 \mathrm{~h}$, all larvae showing signs of starvation fell prey to the cannibals. Interestingly, cannibalism among control larvae in the test without food was higher than among larvae in dishes with a minimal $(0.00125 \mu \mathrm{g} / \mathrm{ml})$ concentration of larvicide (Table 1$)$.

When the same assays were performed at a higher density (60 larval specimens in $20 \mathrm{ml}$ of water per dish) of $1^{\text {st }}$ $2^{\text {nd }}$ instar larvae which received no food, cannibalism was less prevalent than at normal density (Table 2). In contrast to normal density conditions, the numbers of cannibalised specimens increased steadily with increasing the larvicide dose, while their contribution to total mortality remained relatively constant at about $65 \%$ in the range of larvicide concentrations higher than $\mathrm{LC}_{30}$. The difference between the number of cannibalised larvae in test dishes with the 
Table 2. Mortality and cannibalism of $1^{\text {st }-2^{\text {nd }}}$ instar larvae of Culex pipiens exposed to Lysinibacillus sphaericus 2362 larvicide at increased larval density without feeding (mean $\pm \mathrm{SD}$ )

\begin{tabular}{lccc}
\hline & $\begin{array}{c}\text { Larval mortality } \\
(\%) \text { after } 48 \mathrm{~h}\end{array}$ & \multicolumn{2}{c}{$\begin{array}{c}\text { Cannibalism }(\%) \text { after } 48 \mathrm{~h} \text { of } \\
\text { exposure to larvicide }\end{array}$} \\
\cline { 3 - 4 } $\begin{array}{l}\text { of exposure to } \\
\text { larvicide }(\mu \mathrm{g} / \mathrm{ml})\end{array}$ & $\begin{array}{c}\text { from total number } \\
\text { of larvae }\end{array}$ & $\begin{array}{c}\text { from total } \\
\text { mortality (mean) }\end{array}$ \\
\hline 0.0025 & $2.1 \pm 0.9$ & $0.4 \pm 0.2$ & 20 \\
0.01 & $31.3 \pm 9.4$ & $20 \pm 3.8$ & 64 \\
0.04 & $73.8 \pm 19.7$ & $49.6 \pm 9.38$ & 67 \\
0.16 & $97 \pm 2.8$ & $64.6 \pm 11.3$ & 67 \\
Control (no & $7.5 \pm 0.9$ & $7.5 \pm 0.9$ & 100 \\
larvicide) & & &
\end{tabular}

different larval density per dish treated by similar concentrations of larvicide was significant (Tables 1 and 2).

\section{DISCUSSION}

Cannibalism, also known as intraspecific predation, occurs naturally in a wide variety of animals (Fox 1975, Polis 1981, Elgar and Crespi 1992, Toscano et al. 2017), including different taxa of arthropods (Schausberger 2003, Wilder and Rypstra 2008, Santana et al. 2012). It has been documented in many aquatic animals (Sprules and Bowerman 1988, Hopper et al. 1996, Moksnes 2004), including larvae of mosquitoes of different genera (McIver and Siemicki 1977, Reisen and Emory 1976, Clements 1992, Merritt et al. 1992, Renshaw et al. 1993, Koenraadt and Takken 2003, Porretta et al. 2016, Mastrantonio et al. 2018). Larval cannibalism in mosquitoes deserves special attention because of their importance as vectors of dangerous human pathogens. The inter-instar cannibalism, i.e., predation of younger (and smaller) specimens by older (and larger) ones, is more typical of mosquito larvae than the intra-instar cannibalism observed in our experiments. The main factor promoting cannibalism (both inter- and intra-instar) is the absence or deficiency of food, and cannibalistic behaviour is modulated by the hormonal background (El Husseiny et al. 2018).

In our experiments where larvae of Culex pipiens were of the same instars, cannibalism was caused by the absence of food for more than 24-25 h and was directed at specimens with symptoms of poisoning who could not avoid or protect themselves from their siblings. Interestingly, the ingestion of visibly poisoned specimens by apparently healthy ones did not increase the total larval mortality in our experiments registered after $48 \mathrm{~h}$ of exposure (Table 1).

It would be interesting to observe the fate of predator larvae for a more prolonged time taking into account the phenomenon of Lysinibacillus sphaericus spore recycling in mosquito larval cadavers (Becker et al. 1995, Correa and Yousten 1995, Uspensky et al. 1998). In natural water bodies larval cadavers harbouring L. sphaericus spores can remain toxic for at least a year (Uspensky et al. 1998).
Their persistence may aid the elimination of 'fresh' larvae of future generations if the latter feed on poisoned cadavers. The spore recycling was also observed in tests with larval cadavers of several mosquito species after poisoning by another microbial larvicide, Bacillus thuringiensis israelensis (Aly et al. 1985, Zaritsky and Khawaled 1986). While it is clear that this phenomenon depends on a variety of factors including larvicide concentration, larval age and stage, type of food and a number of abiotic components, we are not aware of any recent studies addressing the interaction among these variables.

In the 48-hour experiment with high density of the $1^{\text {st }}$ $2^{\text {nd }} C$. pipiens instars treated with $L$. sphaericus larvicide in the absence of food, the frequency of cannibalism was lower than at normal density. Interestingly, if at normal density cannibalism peaked around $\mathrm{LC}_{50}$ decreasing in both directions, at the increased density cannibalism increased in parallel with larval mortality. We hypothesise that the restricted ability of predator larvae to maneuver in overcrowding conditions when the number of poisoned larvae is small limits their chances of encountering potential prey. The importance of encounters 'favourable' for cannibalistic attacks was shown by Mastrantonio et al. (2018). When many larvae are poisoned, the 'healthy' larvae and perhaps even the minimally poisoned ones have more opportunities to attack and cannibalise the more poisoned specimens even in overcrowded conditions.

Our findings have important methodological implications for assays testing the potency of microbial larvicides. We have shown that at the endpoint of larvicide exposure when the live and dead larvae are scored, some of the initially present larvae may be 'missing', having been cannibalised by their siblings. In order to calculate an accurate value of $\mathrm{LC}_{50}$ for a larvicide under testing, the number of any 'missing' larvae must be determined and added to the number of dead larvae. Accordingly, in assays of larvicide efficacy, it is essential that the total number of live and dead larvae at the endpoint be compared to their initial number, so that any 'missing' specimens could be taken into account. However, the most important point is that optimal conditions of larval maintenance must be supported during the laboratory bioassays. The optimum is specific for any test species and a pesticide tested and it should be determined before the beginning of bioassay.

Acknowledgements. We thank $\mathrm{H}$. Pener and her staff (Laboratory of Entomology, Ministry of Public Health, Jerusalem, Israel) for helping us to start and to maintain our mosquito colony and for permission to use some of their laboratory facilities. We are very grateful to the late Yoel Margalit for his interest and support to our study and helpful advice. The comments of two anonymous reviewers were very useful. The excellent editorial assistance by Ilia Ouspenski is greatly appreciated. This study was partly supported by a grant from the Ministry of Sciences and Technologies, Israel. 


\section{REFERENCES}

Aly C., Mulla M.S., Federici B.A. 1985: Sporulation and toxin production by Bacillus thuringiensis var. israelensis in cadavers of mosquito larvae (Diptera: Culicidae). J. Invertebr. Pathol. 46: 251-258.

BECKER N. 1998: The use of Bacillus thuringiensis subsp. israelensis (Bti) against mosquitoes, with special emphasis on the ecological impact. Israel J. Entomol. 32: 63-69.

Becker N., Margalit J. 1993: Use of Bacillus thuringiensis israelensis against mosquitoes and blackflies. In: P.F. Entwistle, J.S. Cory, M.J. Bailey and S. Higgs (Eds.), Bacillus thuringiensis, an Environmental Biopesticide: Theory and Practice. John Wiley \& Sons, Chichester, pp. 147-170.

Becker N., Zgomba M., Petric D., Beck M., Ludwig M. 1995 Role of larval cadavers in recycling process of Bacillus sphaericus. J. Am. Mosq. Control Assoc. 11: 329-334.

BERRY C. 2011: The bacterium Lysinibacillus sp., as an insect pathogen. J. Invertebr. Pathol. 109: 1-10.

Clements A.N. 1992: The Biology of Mosquitoes, Vol. 1. Chapman \& Hall, London, 509 pp.

Correa M., Yousten A.A. 1995: Bacillus sphaericus spore germination and recycling in mosquito larval cadavers. J. Invertebr. Pathol. 66: 76-81.

Dамвасн P. 2018: New approaches for integrated and cost-effective malaria vector control. J. Rare Dis. Res. Treat. 3: 6-10.

Davidson E.W. 1985: Bacillus sphaericus as a microbial control agent for mosquito larvae. In: M. Laird and J.W. Miles (Eds.), Integrated Mosquito Control Methodologies, Vol. 2. Academic Press, London, pp. 213-226.

El Husseiny I., Elbrense H., Roeder T., El Kholy S. 2018: Hormonal modulation of cannibalistic behaviors in mosquito (Culex pipiens) larvae. J. Insect Physiol. 109: 144-148.

Elgar M.A., Crespi B.J. (Eds.) 1992: Cannibalism. Ecology and Evolution among Diverse Taxa. Oxford University Press, Oxford, $361 \mathrm{pp}$

Fillinger U., Knols B.G.J., Becker N. 2003: Efficacy and efficiency of new Bacillus thuringiensis var. israelensis and Bacillus sphaericus formulations against Afrotropical anophelines in Western Kenya. Trop. Med. Int. Hlth. 8: 37-47.

Fox L.R. 1975: Cannibalism in natural populations. Annu. Rev. Ecol. Syst. 6: 87-106.

Hopper K.R., Crowley P.H., Kielman D. 1996: Density dependence, hatching synchrony, and within-cohort cannibalism in young dragonfly larvae. Ecology 77: 191-200.

Klein D., Uspensky I., Braun S. 2002: Tightly bound binary toxin in the cell wall of Bacillus sphaericus. Appl. Environm. Microbiol. 68: 3300-3307.

Koenraadt C.J.M., TAKken W. 2003: Cannibalism and predation among larvae of the Anopheles gambiae complex. Med. Vet. Entomol. 17: 61-66.

LACEY L.A. 1997: Laboratory bioassay of bacteria against aquatic insects with emphasis on larvae of mosquitoes and black flies. In: L.A. Lacey (Ed.), Manual of Techniques in Insect Pathology. Academic Press, New York, pp. 79-90.

LACEY L.A. 2007: Bacillus thuringiensis serovariety israelensis and Bacillus sphaericus for mosquito control. J. Am. Mosq. Control Assoc. 23 (Suppl. 2): 133-163.

Margalit J., Zomer E., Erel Z., Barak Z. 1983: Development and application of Bacillus thuringiensis var. israelensis $\mathrm{H}-14$ as an effective biological control agent against mosquitoes in Israel. Biotechnology 1: 74-75.
Mastrantonio V., Crasta G., Puggioli A., Bellini R., UrBanelli S., Porretta D. 2018: Cannibalism in temporary waters: simulations and laboratory experiments revealed the role of spatial shape in the mosquito Aedes albopictus. PLoS ONE 13: e0198194.

McIver S., Siemicki R. 1977: Observations on larval Aedes aegypti (L.) as scavengers. Mosq. News 37: 519-521.

Merritt R.W., Dadd R.H., Walker E.D. 1992: Feeding behavior, natural food, and nutritional relationships of larval mosquitoes. Annu. Rev. Entomol. 37: 349-376.

Moksnes P.-O. 2004: Self-regulating mechanisms in cannibalistic populations of juvenile shore crab Carcinus maenas. Ecology 85: $1343-1354$.

Polis G.A. 1981: The evolution and dynamics of intraspecific predation. Annu. Rev. Ecol. Syst. 12: 225-251.

Porretta D., Mastrantonio V., Crasta G., Bellini R., Comandatore F., Rossi P., Favia G., Bandi C., Urbanelli S. 2016: Intra-instar cannibalism in Anopheles gambiae (s.s.) and Anopheles stephensi (Diptera: Culicidae). Parasit. Vectors 9: 566.

Regis L., Da Silva S.B., Melo-Santos M.A.V. 2000: The use of bacterial larvicides in mosquito and black fly control programmes in Brazil. Mem. Inst. Oswaldo Cruz 95 (Suppl. 1): 207-210.

Reisen W.K., Emory R.W. 1976: Cannibalism in Anopheles stephensi Liston. Mosq. News 36: 198-200.

Renshaw M., Service M.W., Birley M.H. 1993: Density-dependent regulation of Aedes cantans (Diptera: Culicidae) in natural and artificial populations. Ecol. Entomol. 18: 223-233.

Santana A.F.K., Roselino A.C., Cappelari F.A., Zucoloto F.S. 2012: Cannibalism in insects. In: A.R. Panizzi and J.R.P. Parra (Eds.), Insect Bioecology and Nutrition for Integrated Pest Management. CRC Press, Boca Raton, pp. 177-194.

Schausberger P. 2003: Cannibalism among phytoseiid mites: a review. Exp. Appl. Acarol. 29: 173-191.

Skovmand O., Becker N. 2000: Bioassays of Bacillus thuringiensis subsp. israelensis. In: A. Navon and K.R.S. Ascher (Eds.), Bioassays of Entomopathogenic Microbes and Nematodes. CABI Publishing, Wallingford, pp. 41-47.

Sprules W.G., Bowerman J.E. 1988: Omnivory and food chain length in zooplankton food webs Ecology 69: 418-426.

Toscano B.J., Hin V., Rudolf V.H.W. 2017: Cannibalism and intraguild predation community dynamics: coexistence, competitive exclusion, and the loss of alternative stable states. Am. Naturalist 190: 617-630.

USPENSKY I. 1996: How to balance our desire to live in an unpolluted environment and the necessity to control bloodsucking arthropod vectors? In: Technological Civilisation Impact on the Environment. International Symposium, Karlsruhe, Germany, 22-26 April, Abstracts, p. 123.

Uspensky I., Klein D., Braun S. 1998: Persistence of Bacillus sphaericus in cadavers of mosquito larvae. Israel J. Entomol. 32: 49-56.

Wilder S.M., Rypstra A.L. 2008: Sexual size dimorphism predicts the frequency of sexual cannibalism within and among species of spiders. Am. Naturalist 172: 431-440.

Zaritsky A., Khawaled K. 1986: Toxicity of carcasses of Bacillus thuringiensis var. israelensis-killed Aedes aegypti larvae against scavenging larvae: implications to bioassay. J. Am. Mosq. Control Assoc. 2: 555-559. Parasitol. 67: 005. 